\title{
The Fiji islands in transition personal reflections
}

\author{
Sitiveni L. Rabuka
}

The years from 1987 to 1999 will no doubt be seen by historians writing about the Fiji Islands' political and social development as the Rabuka years. I am not vain enough, or naive enough, to expect that my story and interpretation of that period will prevail. Already a number of books and scholarly articles have been published about this crucial period in the Fiji Islands-some of them authored at the Australian National University. Naturally I don't agree with all the theories and conclusions.

As the person who was at centre stage from the coups through to the May elections, I welcome this opportunity to offer some personal observations and assessments. Let me take you back to my childhood and some of the people, events and circumstances that helped shape Rabuka the soldier, the military ruler, the politician, the practitioner of democracy and now Commonwealth mediator and peacemaker in ethnic conflict in the Solomon Islands.

I was born in a remote coastal village, Nakobo, in the province of Cakaudrove in Vanua Levu, the second largest island in Fiji. My parents were primary school teachers who in the 1950s and 1960s spent an average of two years on postings in village schools in the province. I am the eldest in my family and I have three sisters. Life for a Fijian boy in a Fijian village in the 1950s was simple and idyllic. I attended the village schools where my parents taught, helped grow vegetables, collect coconuts, cut firewood, weeded the lawn and did other daily chores. In my free time, there was a lot of playing on the beaches, swimming in the sea and the streams, spear fishing, wrestling, playing rugby football on the village green and cowboys and Indians in the bush. I was brought up as a Christian and my father was a lay preacher. In the village, after lunch on Sundays, bible school was compulsory for us children. I listened to my father's and uncles' sermons and decided I wanted to be a lay preacher, too. 
A strong influence in my formative years was my uncle, Sakiusa, who bought me toy pistols, rifles and a mini soldier's uniform. He taught me the 'slope arms', 'order arms', and 'present arms' drill. At the age of ten, I told my teachers I wanted to be an army officer. My father did not agree with this ambition. At the age of nine, I left my parents and spent the next ten years in two boys' boarding schools. Life was strict and regimented in these institutions. At Queen Victoria School, we had military cadet training as part of our curriculum and this strengthened my desire to join the Fiji army.

I was head boy in my last year in school. The English principal of the school relied a lot on me to discipline the boys who were caught smoking, drinking or shirking garden work and classes. In my last year, I helped defuse a strike by senior students and was awarded the G.K Roth prize for leadership. ${ }^{1}$ I was also a leading athlete and rugby player at school and when I left school, I represented Fiji in rugby in a tour of Wales and England in 1970, in athletics in the South Pacific Games in 1971 and as a decathlete at the Commonwealth Games in Christchurch in 1974.

Later in the army, physical fitness helped me set high standards for soldiers under my command and they respected me for that. I played sports with the soldiers and they often asked me for advice and help with their personal problems. I think I can truthfully state that I was a popular officer. I trained in New Zealand and Hong Kong on attachment with the $6^{\text {th }}$ Gurkha rifles in 1974. In 1979 I attended the Indian Defence Staff College in Wellington in the state of Tamil Nadu and graduated with a masters degree in military studies from Madras University. In 1980, I was commanding officer of a Fiji peacekeeping force in South Lebanon and also Chief of Operational Plans for the UN interim force there. In 1983, after attending a course at the Australian Joint Services Staff College in Canberra, I was posted again as Chief of Military Personnel with the Multinational Force in Sinai.

My background-from isolated village to boarding school and thence to the military - was almost exclusively indigenous Fijian. I can see now how narrow and limiting this was. I do not denigrate my Fijian culture and origins. I love them dearly. But there is a larger world we must relate to. My experience overseas broadened my knowledge of life and other people. It sharpened my awareness of what could happen to countries or people of different religions, ethnic origins or cultures. When they are in conflict and unable to settle their differences peacefully, then a vicious circle of violence often erupts bringing untold suffering and tragedy to many ordinary people. In Lebanon and Sinai we were playing peacekeeping roles between nations and communities whose violent divisions seemed to have become unbridgeable. I learnt a lot not only about the role of the military in keeping the peace and law and order, but also about other people from different parts of the world and the complexity of the problems that they and their 
leaders faced. I became aware of the difficulties of building relationships of understanding and trust between people who have inflicted indiscriminate violence against each other. One lesson I learnt was that if you are in a position to influence the outcome of a situation of conflict that is likely to become violent, then you are obliged to do all you can to prevent violence.

That was the main reason I led the first bloodless coup in the Fiji islands on 14 May, 1987 to remove the coalition government led by Dr Timoci Bavadra's Fiji Labour Party from parliament. I had been privy to the plans of the nationalist Taukei movement that had formed after the victory of Dr Bavadra's party and I knew that the leaders of that movement were deadly serious about fomenting a violent campaign against the elected government. The indigenous Fijians are normally regarded as very friendly, accommodating and Christian in their attitudes. But I also knew what they are capable of when they feel threatened as a community and their emotions are aroused. And that was the situation after the defeat of the largely Fijian Alliance Party in April 1987. The Taukei movement was ready to violently oppose the Fiji military forces, whose then commander, Brigadier Ratu Epeli Nailatikau, had promised to the new government that it would not hesitate to use the military to put down any violent protest from the Taukei movement.

I did not agree with this decision because I believed if the mainly indigenous army was used against Fijians it would make matters worse. I came to the conclusion that it would be in the interest of national peace and security that the newly elected government (which I believe was not acceptable to the majority of indigenous Fijians), should be removed. I knew that a national Taukei plan for violent agitation in all the cities and towns was already in place and, having heard its leaders (some of whom were former military men with expertise in explosives and firearms), I knew that nothing was going to deter them from implementing their scheme to violently remove the government and stir up uncontrollable criminal violence. And so I acted. Many people today will still disagree with my judgement and the historic decision I took. But I am at peace with it. The history of Fiji would have been tragically different had I not lanced the boil.

The tension in the relationship between indigenous Fijians and our Indian population had been building up in the 1970s and 1980s. It was fanned by the racial nature of party political confrontation in parliament, and the preaching of the Fijian Nationalist Party. The Nationalists claimed that the Alliance government, led by Ratu Sir Kamisese Mara, had sold out indigenous Fijian interests at the 1970 constitutional talks on the eve of independence. There was a belief amongst indigenous Fijians that the Indian community, with their then majority in numbers and their 
dominance in the private sector, also wanted to politically control the nation. In 1982, a meeting of the Great Council of Chiefs in Bau had resolved that the 1970 Constitution be amended to increase the number of Fijian seats in parliament as a defence against the Indian 'threat.'

In the same year, Ratu Sir Kamisese Mara offered to discuss with the National Federation Party (NFP) - the main Indian political group-the idea of forming a government of national unity. But this was not accepted at the time by the leader of the opposition, Mr Jai Ram Reddy, because I think he felt the proposal was too vague. The emergence of the Fiji Labour Party (FLP) in 1985 with its multiracial platform did not dispel the Fijian belief in the Indian design for political domination, particularly when the FLP decided to form a coalition with the NFP to fight the 1987 general election.

At that time, I shared that belief. Although I understood that the Fiji Labour Party-National Federation Party coalition had won the 1987 general election fairly under the rules, that was not a matter that weighed much in the thinking of the leaders of the Taukei movement in 1987. They saw the new government as a vehicle for Indian domination. On the afternoon of 14 May 1987, I had a meeting with Fiji's media bosses to establish the new rules for the media after the coup, and this is part of what I said to them.

It is your responsibility to pass on information, but be sure that none of the releases would inflame racial tension. As a Fijian, I am concerned about what the Fijian community can get up to. It would ruin the nation. What I have done this morning is a preemptive move to stop Fijian groups developing into terrorism or the Republic of Fiji Military Forces being used against the people.

I also said I would appoint a council of ministers drawn from the civilians, as a 'caretaker government', backed by the military, until a new Constitution was drawn up and a fresh election held under it. The Governor-General, Ratu Sir Penaia Ganilau, was to be re-appointed as Governor-General. I reassured the press that it would be free to publish the views of those who opposed the coup. The detained government leaders were to be released the next day and I added: 'They have done nothing wrong, and it is my responsibility to see they are comfortably looked after' (Thomson 1999:16).

The coup was seen in Fiji and overseas as not only a rape of democracy but also a racist anti-Indian act. For years after that, I was regarded as a 'racist', but this was what I said five days after the first coup in a radio broadcast

To the Indian community I feel very deeply for your welfare. You belong here...You are part of our history and future. Please be assured that you have absolutely nothing to fear from this administration. 
And this is what I said to the Indian soldiers under my command in September 1987

To the Indian soldiers who are here, do not be alarmed or frightened about what I am saying. If you believe in me, work with me...We are fighting for the Fijians and not forgetting the welfare of other races in Fiji.

I was and I am still a Fijian nationalist in that I have a deep commitment to the welfare and interests of the indigenous Fijian people. I am also a firm believer in peaceful and harmonious co-existence between people of different cultures, religions and beliefs. My main concern from the beginning was-and still is-that in the Fiji Islands it is vitally important that the indigenous Fijians must feel politically secure. If indigenous Fijians do not feel secure, then it will be bad for ethnic relations and the government elected to power. If the Fijians feel secure, then other communities will also feel the same about their place and future in the Fiji Islands. In 1987, I saw these issues about security and identity predominantly from the indigenous Fijian standpoint. The Taukei movement in 1987 wanted to impose Fijian political power and preeminence regardless of what members of the deposed government and its supporters felt.

The Fijians had largely viewed the 1987 general elections result as a show of gross disrespect to them as the host community, because a Fijiandominated Alliance government had been voted out of office by those who were regarded as 'vulagi', or guests. That was the political view of the situation from the Fijian cultural perspective and it does not sit well with the western democratic tradition that governments are elected and voted out of office by the will of the majority who, irrespective of their culture or history, are citizens with equal rights. In Fijian indigenous culture the concept of equal rights was foreign. It is the landowners and their chiefs who have predominant rights, which include the rights to assert what they believe belongs to them and to express that to others and the outside world. This belief also determines the attitude of most Fijians in the modern political arena. In other words, they believe the state should be under Fijian control, the national Constitution should express the values and symbols of Fijian culture and the citizens who are not of indigenous ancestry should understand and accept the Fijian attitude to legitimising institutions and social order in the nation. That may sound authoritarian and intolerant, but the indigenous Fijians also pride themselves on being accommodating, flexible and generous. If people who are not indigenous respect the Fijian view and develop a genuine sensitivity to the Fijian culture and the Fijian ways of accommodating the interests of others, then ethnic relations would have a very sound basis for development. 
The victory of the FLP-NFP coalition in April 1987, with minority support of indigenous Fijians, was seen as not just a challenge but a threat to this Fijian belief. The extremists in the Taukei movement, as I have said earlier, were prepared to meet that threat with sustained and widespread violence. I conducted the coup to seal off that path and to move the country to a form of civilian constitutional rule that would be acceptable to the Fijians. The meeting of the Great Council of Chiefs five days after the first coup, on 20 May 1987, expressed the Fijian view and also endorsed the late GovernorGeneral, Ratu Sir Penaia Ganilau's promise to move the nation cautiously towards a system of government that would be acceptable. At the time, it was hoped that what would be acceptable to the indigenous Fijian would be accepted by those who supported the deposed government. This was for the sake of returning Fiji to political stability, harmonious communal relationships and economic recovery. I subscribed to this view and maybe, in hindsight, I was very partisan and in a sense politically naive. However, in the circumstance of the time, no other view made sense to me. Acceptance of the view of members of the deposed government, that they had been unjustly deposed by a racist coup was out of the question and even the idea of accommodating them in the Governor-General's council of ministers was difficult for the Taukei movement to accept. Peter Thomson, the Secretary to the Governor-General described the situation after the coup very well.

Spontaneous street violence spread to Nausori and Suva's surburbs, where mobs looted, assaulted and stoned people and property. That day's rioting was another confirmation that we were at the edge of a precipice of awful consequence. Up at Government House, the security briefing conveyed a message of incipient racial retribution and the reality of this threat and our duty to combat it underlaid all our efforts. For the duration of my time at Government House, the containment of the forces pushing Fiji towards that precipice assumed priority over all other issues and crises. I am happy for those who conclude the threat was over-stated. I don't believe it was, and it was the chief reason that, in spite of all he put awry in 1987, I recognised the willpower of Sitiveni Rabuka and the stop he put to overt communal violence in Fiji.

The objective of the 1987 coups as confirmed by the Great Council of Chiefs on 20 May 1987, was to change the Constitution in favour of the indigenous Fijians. It meant political control through an increase in the number of Fijian parliamentary seats, the protection of Fijian economic interests and provisions for affirmative action for indigenous Fijians to improve their position in education and commerce. The aim was to bring them on a par with other communities. It was also an assertion of the 
indigenous Fijian identity and the leadership role of the chiefs. Fijians, it was felt, held the key to political stability and economic development in the interest of all communities.

Ratu Sir Penaia Ganilau and Ratu Sir Kamisese Mara agreed with the Great Council of Chiefs' objectives in May 1987. But when the Deuba Accord was signed in September that year in a move to form a bi-partisan government there was no specific commitment, only a broad statement to review the 1970 Constitution. I learnt that deposed members of the Bavadra government were strongly opposed to the resolutions of the Great Council of Chiefs and my involvement in their discussions. If the deposed government had agreed that the Constitution would be reviewed and taken into account the resolutions of the Great Council of Chiefs, the Fiji military forces would have supported the government of national unity proposed under the Deuba Accord signed on September 24, 1987. That is why I took over the government again the next day. After a critical statement from the Queen, I received legal advice and decided to declare Fiji a Republic. It meant the end of the office of Governor-General and loss of membership of the Commonwealth. A new Interim Constitution was promulgated by decree on October 6.

In 1987, my view of politics and religion was simple. I believed then that if my Indian brothers and sisters could be converted to Christianity, then the relationship between the two main communities would be less tense, and we would have more in common. That is why I then favoured having Fiji declared a Christian state under the Constitution. My intention in 1987 was always to hand back political power to experienced civilian leaders, after ensuring that the objectives of the coups had been achieved. This I did after both coups - back to Ratu Sir Penaia Ganilau and Ratu Sir Kamisese Mara. I felt at ease after handing over the reins to those two chiefs in December 1987.

\section{The 1990 Constitution}

I supported the promulgation of the 1990 Constitution. I believed then that the Constitution had achieved the objectives of the coups as I contained all the measures that the Council of Chiefs and the great majority of Fijians wanted to be recognised and expressed. At the time I was not inclined to accept the criticism of the 1990 Constitution from outside Fiji, which seemed merely to mirror the Fiji Labour Party and National Federation Party positions. I felt that overseas critics, and especially the labour governments and trade unions in Australia and New Zealand, were interfering in Fiji's internal affairs and that they should exercise restraint in expressing views on a situation they did not understand very well. I believed the critics were trying to impose on the indigenous Fijian people western models and values of democratic government that were not acceptable to them and therefore 
inappropriate; but because of my growing belief that we had to find a way forward that would satisfy all the communities in Fiji, I came to regard the 1990 Constitution as an interim arrangement. It was to be a vehicle to get us back to parliamentary government, with the expected participation of the opposition parties. After the general election of 1992, we would then be in a position to review it. The 1990 Constitution had provisions at any rate requiring that it be reviewed within five years of the 1992 general election. I knew then that we would not be able to ignore the demands of the opposition parties once they were in the parliament.

Both NFP and Labour had participated in the 1992 general election for two reasons: to change the 1990 Constitution to make it acceptable to the Indian community, and to secure the renewal of the Indian tenants leases under the Agricultural Landlord and Tenants Act (ALTA) on satisfactory terms. The Fiji Labour Party, which had promised its supporters it would contest and win Indian communal seats and then boycott parliament, did an about-turn after the election and backed my appointment as prime minister by the first president of the Republic, the late Ratu Sir Penaia Ganilau.

I was by then the leader of the Soqosoqo ni Vakavulewa ni Taukei (SVT) Party founded by a resolution of the Great Council of Chiefs in June 1990, to be the main unifying political party for the indigenous Fijians. I had decided that if the gulf between the Fijian and Indian communities was to be closed and our differences reconciled, then I, as the person who had conducted the coups and widened that gap, should stay in the political arena and take a lead in the rebuilding of relationships. I had to take on the challenge of transforming attitudes and beliefs and accommodating interests on both sides, so we could arrive at a consensus. But after the 1992 general election, we had to tread cautiously because most of the members of the SVT were opposed to any significant changes to the 1990 Constitution. These people believed that the 1990 Constitution was the best for the indigenous Fijians and that it would be unwise to change it so soon after its promulgation. I had to proceed much more slowly than the impatient Fiji Labour Party wanted. That led to a rupture of the relationship between the SVT and the FLP which walked out of parliament in 1993, blaming me for breaking what they believed was an undertaking to immediately introduce the democratic Constitution they desired.

In the budget debate in 1992, I had proposed that my government and the opposition parties form a government of national unity. I felt changing the Constitution would be easier if the opposition came into the government. There was not much support for the idea from my caucus colleagues. The leaders of the Indian parties were also cautious, because there was a belief that government could use such a development as an excuse not to move on major changes to the Constitution. Nevertheless, I 
began informal meetings between myself, the leader of the opposition, $\mathrm{Mr}$ Jai Ram Reddy, and the Leader of the Fiji Labour Party, Mr Mahendra Chaudhry. This is how I recalled our first meeting on 24 December 1992, in my speech introducing the Constitution (Amendment) Bill about four and a half years later.

We sat in my office and devoted our entire meeting to sharing our views and vision of the land that we share, the kind of country that we would like Fiji to be...We agreed that although as individuals, the people of Fiji belong to different ethnic groups, and whilst as communal groups we differed in our perception of the needs and interests of our communities, we believed nevertheless there was ample common ground to bind and unite everyone together. We all belong to this country, to this nation Fiji. We are one nation. We all want a better, secure future. We all want permanent peace for our country and its people. We all want to build a nation where each one of us, as individuals and a community, can freely develop and prosper, where we can all be happy and where there can be justice for all.

That informal meeting of the leaders evolved into a broader subcommittee of Cabinet, which agreed to terms of reference for the review of the 1990 Constitution. I want to digress a little here to say that at that time, a faction had developed in the SVT which was opposed to my leadership. It was led by the late Josevata Kamikamica, who I had defeated in the first caucus leadership vote after the 1992 general election. This group, in the presentation of the budget at the end of 1993, voted against it and forced us into another general election barely a year and a few months after the first one. This was the beginning of the break-up in the party I led. That group started the Fijian Association Party (FAP), now the largest Fijian party in parliament in seat numbers and in coalition with the Fiji Labour Party led by Prime Minister Mahendra Chaudhry.

To return to constitutional development, the Joint Committee of Cabinet, which included the opposition leaders, also agreed to the appointment of three members of the Constitution Review Commission and a constitutional adviser. And as you know, the Chairman was Sir Paul Reeves, former Governor-General of New Zealand; Tomasi Vakatora, an experienced former senior civil servant, senior minister and Speaker of the House under Ratu Sir Kamisese Mara's Alliance Government; and Professor Brij V. Lal, a Fiji-born academic. The constitutional adviser was Mrs Alison Quentin-Baxter, a very distinguished constitutional lawyer from New Zealand. We were fortunate to have such a good team who consulted widely in Fiji and overseas and produced a comprehensive and enlightening report with 694 recommendations. 
The report was tabled in parliament in 1996 and a Joint Parliamentary Select Committee (JPSC) consisting of members from both sides of the house and the senate was appointed to study it and decide on the recommendations. I decided to be chairman of the committee at that stage of the negotiations because I believed I should steer the deliberations towards the consensus needed to take us to the drafting stage. There was strong dissent within my party to my involvement in the negotiations. It came from those who believed that accepting the changes recommended in the Reeves Commission report would mean political suicide for the SVT. They argued the Fijian people would not tolerate any drastic changes to the 1990 Constitution. I knew the risks, but I was convinced that what was more important was for us in the committee to provide collective leadership in steering the country toward a new constitutional settlement. I thought that if about half of Fiji's population (that is mainly the supporters of the opposition parties) did not regard the 1990 Constitution as their Constitution, then it could not be a sound basis for a democratic system of government to unite all the people of Fiji. My reading of the report of the Commission told me that not only had they done a thorough examination of all the relevant issues, but they had also provided very practical compromise recommendations for changes based on sound principles of law. All the interests of our different communities could be accommodated and expressed in the new vision of the Reeves report. I remember sharing with members of the Parliamentary Select Committee these words of Nobel Peace Prize winner, Archbishop Desmond Tutu

Some people think reconciliation is a soft option, that it means papering over the cracks. But the biblical meaning means looking facts in the face and it can be very costly; it cost God the death of his own son.

Those words underscored what I felt about the reconciliation we had to go through. Our side had to be prepared to make sacrifices in negotiating a new Constitution which would meet the test of acceptability for all the communities in Fiji, and the international community, whilst strongly protecting the special position of the Fijians. I had to face the fact that many members of my party and even leading members of our side in the Joint Parliamentary Select Committee, did not fully share my view on the Reeves report. In meetings over a period of two months, we were able to agree to most of the recommendations of the report. We had with us then skilled Australian lawyer, Dennis O'Brien of Minter Ellison in Canberra, who drafted the new Constitution.

Whilst the Joint Parliamentary Committee sat, my caucus was also discussing the issues and I had to put my leadership on the line a number 
of times. Some of my Fijian members had taken the Reeves report to their local provincial councils and got them to pass resolutions either opposing or condemning it and favouring the retention of the 1990 Constitution without amendment. These developments were widely reported in the news media, creating the impression that the JPSC and Fijian politicians in favour of change were out of touch with grassroots feelings. There wasn't time to go to the people and fully explain the recommendations of the Reeves report or the work of the Commission. Because of the time limit placed on us by the 1990 Constitution, we had to complete the exercise, and get the Constitution Bill into parliament by June 1997.

The best way open to me for convincing my opponents in the party and the doubters in the Fijian community was to take the issue to the Bose Levu Vakaturaga, or Great Council of Chiefs, for the Chiefs' support. I thought there was no one better to put the case than the eloquent leader of the opposition, Mr Jai Ram Reddy. Inviting him to address the chiefs was in itself significant politically and was in keeping with the spirit of national togetherness we were trying to create. It was the first time an Indo-Fijian had made a speech to the Council. I quote part of what Mr Reddy said to the chiefs

The Indians in Fiji, brought to these shores as labourers, did not come to conquer or colonise. We, their descendants, do not seek to usurp your ancient rights and responsibilities. We never have. We have no wish, no desire, to separate ourselves from you. Fiji is our home. Fiji is our only home. We have no other. We want no other. Our ancestors came to this land in search of a better life, in search of a future they dreamed of for their children and their children's children. Though they travelled to these islands long, long after your ancestors, surely the dreams and hopes of those who landed from the Leonidas were not that different from those who came ashore after the epic earlier voyages from the west. You are the chiefs of all the people of Fiji. The Indians of Fiji honour your place, and the place of your people, as the first inhabitants of Fiji. We seek not to threaten your security, but to protect it. We seek not domination; indeed, we cannot dominate: we are not the majority ethnic group in this multiracial nation-you are. What we seek is a partnership. We seek a country whose children of all races can grow up with deep understanding and respect for each other's cultures, languages and traditions. I am convinced the indigenous interests you have a solemn obligation to protect are in no way weakened under the arrangements we the members of the JPSC are proposing. 
In an address to party supporters in Sydney on April 10 1999, Mr Reddy said this

The memory of that meeting of the Great Council of Chiefs will remain with me to my dying day. All of us present had kept an appointment with history. The distance between us was closing and the future called.

Indeed, Mr Reddy's speech to the chiefs was a defining moment in our history and sealed the support of the Bose Levu Vakaturaga for the new Constitution. At the end of my speech in introducing the Constitution Amendment Bill on 23 June 1997, I said this

Before concluding, Mr Speaker, I wish to particulary thank most sincerely, the members of my own party the Soqosoqo ni Vakaulewa ni Taukei, most of whom have had to shed our indigenous nationalism ideals and their separatism, and take on instead the most noble role of expanding our horizons to embrace the positive and allembracing national patriotism for the good of this beloved country and all its people I will quote a verse from the Bible. As Paul wrote in his letter to the Phillipians, Chapter 3:13: 'Forgetting what is behind and straining toward what is ahead, I press on toward the goal for which God has called me heavenward in Christ Jesus'.

You know about the election results, how our SVT coalition with the NFP was decimated, and Labour and its partners won a landslide victory. The poetic irony is that Mr Reddy and I, the main architects of the 1997 Constitution, which was designed to bring about greater national unity, were essentially rejected by the voters. That was the price we had to pay for bringing in so much change in the process of Fiji's transition. Mr Reddy was probably punished by the Indians for getting too close to Rabuka, the coup-maker. My own SVT Party lost ground because it was seen as selling out the Fijians. But our multiracial vision for the country was right and I have no regrets about embracing it.

Labour Leader Mahendra Chaudhry was nominated as prime minister and duly appointed. That, of course, was another historic development. For the first time an Indo-Fijian had become head of government. Our new system of democracy was being tested to the full. Only a few years ago such an appointment would probably have taken us to the brink, and possibly beyond. Even now, there are those who are not comfortable with it-and indeed some who are vehemently opposed. We had some attempts to create civil unrest, but they came to nought. I understand there was an effort to persuade some army officers to intervene. The overtures were not 
well received. Within my own camp, defeated candidates started making nationalistic sounds similar to those of 1987.

But this time the circumstances were different. Many Fijian voters had deserted our party, so we could no longer claim to be the sole, authoritative voice of the indigenes. Other parties with significant Fijian backing had joined with Labour in government. To that extent the Constitution was successful in creating a viable multiracial administration. That was what it was designed to do. I had to explain that we would have been living a lie if we refused to accept the result of the election under the Constitution we had created and agreed to. We had declared that we were committed to its objectives. How could we turn around and reject it just because the elections had not gone in our favour?

The Constitution provides for winners and losers. We had lost and that was it. That was democracy and now it is at the centre of our arrangements for governance.

I vacated office and wished Mr Chaudhry and the new government well. Initially I had intended to be leader of the opposition. But following concern about my leadership, I decided to step aside. Then, surprisingly, I was appointed to the new post of chairman of the Great Council of Chiefs. This was a great honour, with heavy responsibilities. I tendered my resignation to parliament because I felt the Council chairman should be politically independent. Shortly afterwards, I was asked to become Commonwealth mediator to help restore peace and stability to the Solomon Islands, which have been gripped by ethnic tension and unrest. I am thankful to God that what I have learned about reconciliation and conflict resolution equipped me well for that task in the Solomons.

I want to end by briefly discussing my religion, for it has played a great part in whatever I have been able to achieve in bringing greater democracy and equality to Fiji. I am not-as some might think-a fundamentalist Bible basher. But I do have a deep belief in the teachings of Jesus Christ. He is my lord and my saviour and even though I fail Him often, I try hard to return to the fold and follow His way. My commitment to the Lord has strengthened me throughout my political life. I lean on Him to gain inspiration, to learn more about spreading goodwill, tolerance and understanding. There is a universal spirit of Christ which has a place and a voice in all religions. This is what I believe. I took great comfort during some of my most trying times in sharing with a multireligious, multiracial group of friends, brought together regularly in the name of Jesus. Among them I could express my innermost fears and thoughts away from the immediate pressures of politics. I went away from many of those gatherings with new resolve and with my spirits lifted. Those friends in Christ and 
many others from overseas continue to be a pillar of strength. When I was in the Solomons their thoughts and prayers were with me. I have no doubt whatsoever that this helped me achieve the first stage of my mission there. When I look back now to the defeat of the elections, and to what happened afterwards, I know that when you try to walk in faith you will be cared for and things will work out in the end, according to His will.

I hope this has widened your understanding of the Fiji Islands, their political and racial challenges and the significance of the Rabuka era.

\section{Note}

1 Roth, G.K. (1903-60) served as an Administrative Officer in Fiji in the 1920s, rising to become the Secretary for Fijian Affairs in 1954. He was the author of Fijian Way of Life (1953), Oxford University Press, Melbourne [Editor]. 